\title{
The dynamics of Asian business systems in a globalizing era Henry Wai-chung Yeung
}

Department of Geography, National University of Singapore

\begin{abstract}
Globalization tendencies are transforming the nature and organization of business systems. This is particularly the case in the Asia-Pacific region where business systems are socially and institutionally embedded. In this article, I argue that the dialectical tendencies of globalization towards homogenization and differentiation have differential impacts on the configurations and dynamics of Asian business systems and their constituents. While these business systems tend to be relatively enduring over time because of their historical legacies and institutional embeddedness, major business firms emerging from these national business systems may be much more susceptible to changes brought about by globalization tendencies. This is because actors and elites in Asian economies are increasingly enrolled into global actor networks which in turn reshape how these Asian actors conceive and operate their business firms and/or political-economic networks. It is possible that globalization has only limited effects on Asian business systems at the structural level but significant transformational impact on Asian business firms at the level of key actors. I show how the two-way enrolment of global actors into/from Asian business systems can contribute to significant transformations in the dominant forms and organization of these business systems.
\end{abstract}

\section{KEYWORDS}

Globalization; business systems; Asia; actor networks; institutions; political economy.

\section{INTRODUCTION}

It is common for researchers in international political economy to argue that there are distinctive ways of organizing business institutions in different parts of the world. This stability in business patterns and organizations often persists in the face of rapid political-economic change external to the societies concerned. Together, these patterns of social and 
organizational structuring form different business systems that refer to a phenomenon of relatively stable and enduring patterns of business practices in specific localities and societies. Whitley (1992: 13) defines business systems as 'distinctive configurations of hierarchy-market relations which become institutionalized as relatively successful ways of organizing economic activities in different institutional environments'. To him, business systems are distinctive and enduring ways of structuring market economies that are wide-ranging and long term in nature. Once established in particular institutional contexts, these business systems may develop considerable cohesion and become resistant to major changes. Even such powerful changes as internationalization and globalization are deemed to have only limited effects on the nature of business systems (Whitley, 1994, 1998, 1999). Even after they are transformed, these distinctive systems of economic organization would 'bear the marks of conflicts between opposing conceptions of capitalism and their allied institutional arrangements and interest groups (Whitley, 1998: 447). Their evolutionary trajectories are seen as dependent on pre-existing configurations of domestic social, economic and political institutions (see also Whitley and Kristensen, 1996, 1997; Grabher and Stark, 1997).

This business systems perspective is particularly relevant in analyses of the political economies of the Asia-Pacific region where national business systems are socially and institutionally embedded. In the words of Backman (1999: 365), '[o]ld habits are hard to break' in the context of opaque and corrupted business systems in some Asian countries. To some observers, these business systems in Asia are characterized by the differentiated role of inward-looking inter-firm networks, excessive reliance on personal relationships in business transactions, and strong intervention of the state in business and the economy (see later sections). These qualitative differences in business systems constitute a mosaic of distinct political economies in Asia.

The question I want to raise in this largely analytical article is whether Asian business systems can be as stable and enduring in today's context of accelerated globalization. Globalization is defined here as a set of dialectical processes that simultaneously create a functionally interdependent world economy and accentuate the importance of all kinds of differences in societies and space. These processes include global flows of materials (e.g. people, goods) and intangibles (e.g. capital, technology, information and services). My argument here is that in assessing the impact of globalization tendencies, it is important to distinguish between business systems as enduring national structures, and key actors in these systems as agents of economic change. The lack of attention to actors and their strategies/behaviour as agents of organizational and system change is a major lacuna in the business systems perspective. Indeed, Whitley (1996: 414) offers a self-critique that his perspective 
tends to downplay the significance of particular firms' actions in favour of the more general logic of particular institutional systems. ... [It] has not paid a great deal of attention to international forms of economic organization, or how the growing cross-national interdependence of some firms and markets has affected national business systems.

He suggests that future studies should concern the ways in which the growing internationalization of economic activities has affected interdependencies between firms and their domestic business environments and the mechanisms by which the roles of economic actors 'become institutionalized and reproduced... as well as the circumstances in which they are liable to change' (Whitley, 1996: 423). Sharing the same vision for organization studies, Gereffi (1996: 437) concludes that 'traditional boundaries between nations, firms, and industries are being reconfigured, and organization theory as well as development theory need to find ways of encompassing all the relevant actors within a single framework'.

In this article, I aim to show how globalization tendencies can transform the dynamics of Asian business systems and, subsequently, their nature and organization. I argue that the dialectical tendencies of globalization towards homogenization and differentiation have differential impacts on the configurations and dynamics of Asian business systems and their constituents. On the one hand, globalization tendencies may undermine certain social and institutional foundations of Asian business systems, and accentuate the need for transformations in their traditional dimensions. Today, many Asian business firms face the dilemma of succumbing to the pressures of transparency in order to secure global finance while preserving their traditional practices of network reliance and intricate family ownership and/or control. In this context, there are fewer competitive advantages derived from the reliance on personal relationships on the basis of intra-regional business networks. Instead, the spatiality of business networks has been relegated from the intraregional scale to the global scale so that global actor networks are increasingly influencing Asian business systems. Globalization has made possible the complex interpenetration of global actor networks into Asian business systems. On the other hand, globalization tendencies continue to reinforce local differences in business conduct and discursive practices. This tendency towards local differentiation is also a process of creating and reforming hierarchies and structures of national economies. The local embeddedness of firms in national business systems remains a key source of competitive advantage. This localization process enables Asian business systems to retain some core attributes in an era of accelerated globalization. The dynamics of Asian business systems depend 
critically on globalization tendencies as a major transformational force in the global economy today.

While, as argued by their proponents, Asian business systems tend to be relatively enduring over time because of their historical legacies and institutional embeddedness, major business firms emerging from these national business systems may be much more susceptible to changes brought about by globalization tendencies. This is because key actors in these Asian firms are increasingly participating in and enrolled into global actor networks which, in turn, reshape how these actors conceive and operate their domestic business firms/networks. Although business systems are much more structurally embedded in specific national social organizations and political-economic institutions, actors in business firms are significantly more mobile and receptive to change. It is possible that globalization has only limited effects on Asian business systems at the structural level and, yet, significant transformational impact on Asian business firms at the level of key actors. The nature and degree of enrolment by Asian actors into the global economy therefore explain the dynamics of Asian business systems and their differential impact on specific actors and their embedded business systems. Facilitated by globalization, this enrolment process enables actors to experience different organizational and business practices abroad. It also allows these actors to transform their own business firms and networks, subject to some binding effects of their domestic business systems. If these dynamic changes occur collectively among business firms in a clearly defined business system, fundamental institutional changes may be forthcoming and this may result in significant changes in the dominant forms and organization of the national business system itself. In this way, business systems are conceived as 'open systems' and are subject to dynamic changes from within, i.e. at the level of actors themselves.

This focus on actors and their enrolment into global networks at different spatial scales is important in this analysis for at least two reasons. First, this bottom-up approach examines the dynamics of globalization and national business systems as they operate at the level of actor networks. This contrasts with and, yet, complements the overwhelming top-down approach in much of the literature on globalization and the political economy of business systems (cf. Mittelman, 2000). Second, whereas business firms and their strategies may be conceived as agents of economic change at the structural level, it is clear that these firms are controlled and managed by specific social actors (see also Yeung, 1998a). By focusing on the action and behaviour of these social actors (e.g. their enrolment into global networks), we are better able to unpack the monolithic view of the firm as a coherent and stable feature of capitalist economies. The actor network approach in this article helps us to appreciate the differentiated strategies and 
behaviour of business firms as deliberate responses by social actors to the changing contexts of globalization and dynamic processes in business systems.

This article is organized into three sections. The next section examines briefly the dialectical tendencies of globalization to set the context of this article. This is followed by a theoretical analysis of the impact of globalization on the changing configurations and dynamics of Asian business systems. In particular, I draw upon actor network theory to describe the enrolment of Asian actors and elites into networks at different spatial scales and to show how these processes of enrolment are facilitated by globalization tendencies. I also discuss the impact of these actor networks on the dominant forms and organization of Asian business systems. The concluding section summarizes my main arguments.

\section{THE DIALECTICAL TENDENCIES OF GLOBALIZATION}

To date, an overwhelming body of literature has been devoted to 'globalization' - both as a contested set of discourses and as a transformational force in the global economy. As a set of discourses, globalization encapsulates certain political agendas, in particular neoliberalism, to create its own conditions of existence (Yeung, 1998b; Kelly, 1999). As a set of material processes, globalization is constituted by intensified flows of tangible and intangible forms across societies on a global scale. It is, however, beyond the scope of this article to review this huge body of literature (see Hirst and Thompson, 1996; Mittelman, 1996, 2000; Cox, 1997; Doremus et al., 1998; Held et al., 1999; Olds et al., 1999). I have explained in detail elsewhere the underlying logic of the complex interrelationships among capital, state and space under conditions of globalization (Yeung, 1998b). In this article, I want to emphasize one critical dimension of globalization - its dialectical nature towards both spatial integration (a result of the globalization of economic activities) and spatial disintegration (an outcome of localization of these very activities). This is an important point because it has often been assumed in the ultra-globalist literature that globalization represents a single and uni-directional socio-spatial logic towards the homogenization of everyday social life and economic practices. These enthusiastic proponents of globalization envisage an end-state view in which a borderless world emerges (see Ohmae, 1990, 1995; O'Brien, 1992; Horsman and Marshall, 1994). On the other hand, it is unfortunate that its critics have taken too seriously this end-state view towards the homogenization of national economic and institutional structures that are collectively known as business systems. This latter group of scholars argue that despite globalization processes, differences in economic organization 
between capitalist economies continue to create different varieties of 'capitalisms' (see Berger and Dore, 1996; Crouch and Streeck, 1997; Hollingsworth and Boyer, 1997; Orrù et al., 1997; Hefner, 1998; Whitley, 1999). They view ultra-globalists as adhering to a form of economic functionalism which 'assumes that market competition inevitably replaces inefficient economic systems by more efficient ones, and that global competition will produce a new transnational system which will out-compete the many current varieties of capitalism' (Whitley, 1998: 447).

These two opposing views of globalization - one for homogenization and another for continual differences - obfuscate the dialectical and transformational nature of globalization. We are left with an either/or choice when it comes to how to grapple with the problem of understanding the complex tendencies of globalization. One has to believe either in the powerful role of globalization in homogenizing different national business systems or in the stubborn resistance of these business systems to change brought about by globalization tendencies. I believe that these dichotomous views of globalization tendencies are false because they are based on static premises and fail to acknowledge the dynamic nature of both globalization tendencies and business systems. First, the ultra-globalists are clearly guilty of their singular and unidirectional end-state logic of a borderless world in which national differences cease to exist. They fail to recognize that the very logic of globalization itself is highly contested in a reflexive manner by multiple actors (e.g. individual elites, business firms, nation-states, international organizations and so on) at different spatial scales (e.g. local, regional, national and global). Indeed, this multiplicity of contests provides the central dynamic to globalization tendencies. There is, for example, no convincing reason to expect a business firm to follow the same globalization logic as a nation-state. This is clear in the case of Chinese business firms from South-East Asia that often operate on the basis of such actorspecific motives as familism and personal relationships, rather than such state-specific rationality as ethnic redistribution and nation building (see Yeung, 1999a, 1999b, 2000b). As such, globalization operates as a set of complex and conflicting tendencies, the outcomes of which often cannot be predicted.

Second, the globalization critics have overemphasized the distinctiveness of national business systems and institutional structures, and caricatured globalization tendencies as necessarily eroding national differences. Just as national business systems are strongly embedded in domestic social and economic institutions, and exhibit certain defining norms and characteristics (e.g. 'business as usual'), they are surely not organizational blueprints that are for ever cast in stone. Instead of asking what the new form of global capitalism is and how it replaces existing 
national systems of capitalism(s), the appropriate question should be concerned with what constitutes the central dynamics of existing national business systems and how this dynamics can be unleashed under different contextual circumstances. Globalization helps to create one such changing circumstance that is particularly powerful in the late twentieth century. In an era of accelerated globalization, it becomes inevitable for us to consider the reconfiguration of national business systems as 'open' rather than 'closed' systems. Insofar as we view globalization as a set of highly contested tendencies and processes, such a consideration of reconfiguring business systems need not be contingent upon the arrival of a globalized world or the satisfaction of certain stringent conditions for the establishment of global forms of economic organization. This is because if a globalized world does ever come, it is no longer intellectually interesting to consider how national business systems have been reconfigured. The real analytical challenge rests with the processes of reconfiguration rather than the end product itself (e.g. the demise of national business systems and the emergence of one dominant form of capitalism). This, I believe, is a very important point missed by critics of globalization. Given the dialectical and contested nature of globalization tendencies, one wonders whether such an end-state of either a dominant form of global capitalism or a mosaic of national business systems will ever arrive. If not, isn't it more meaningful to focus on the dynamic processes of change and reconfiguration?

So far I have not unpacked what I mean by the dialectics of globalization. Given the space limit here, I can only briefly outline the key transformations of globalization (see also Dunning, 1993; Hirst and Thompson, 1996; Dicken, 1998; Held et al., 1999). In the first place, there is no doubt that the global economy today has become much more functionally integrated and interdependent than ever. To a large extent, this increasing integration and interdependence of national economies on a global scale is explained by the cross-border activities of transnational corporations (TNCs) and their associated flows of direct foreign investment (DFI). In 1997, the value of international production, attributed to some 53,000 TNCs and their 450,000 foreign affiliates, was US\$3.5 trillion (measured by cumulative DFI stock) and US\$9.5 trillion (measured by estimated global sales) (UNCTAD, 1998: 2). This globalization of production has invariably led to greater competition between firms embedded in different business systems. As the rules of competition are altered (see Best, 1990; Porter, 1998), there is a growing trend among leading firms in global industries to innovate relentlessly and to adopt strategically selective practices by their competitors. This process has been viewed by both camps of globalization as homogenizing national business systems towards a more 'efficient' model of global capitalism and global competition. 
What is missing in this interpretation is the possibility for the emergence of new organizational forms among firms in global competition. Instead of producing a global economy based on the Anglo-Saxon model of competitive capitalism, globalization tendencies have generated rather different and pluralistic geographical organizations of economic and social life connected by global spaces of flows. One of the central mechanisms through which these spaces of flows are interconnected is the rise of the so-called 'network society' (Castells, 1996) and 'spaces of network relations' (Yeung, 1998a). The past decade has witnessed the emergence of the 'connected corporation', 'differentiated network', 'alliance advantage' and 'alliance capitalism' (Lewis, 1995; Dunning, 1997; Nohria and Ghoshal, 1997; Doz and Hamel, 1998). These terms refer to significant qualitative changes in the organization of firms, business systems and capitalism(s). There is a greater tendency towards the formation of strong intra-firm networks to exploit firms' core competencies and the formation of different inter-firm networks through equity and non-equity arrangements (Contractor and Lorange, 1988; Buckley, 1994; Yeung, 1994, 1998c; Beamish and Killing, 1997). In organizational terms, globalization tendencies have led to both convergence and divergence in the ways of economic coordination and control. While certain organizational forms (e.g. Fordist mass production) continue to exist, other new organizational forms (e.g. strategic alliances) emerge to become important modes of economic coordination and control.

Although globalization is defined by convergence in the spatial organization of economic activities, it also accentuates geographies of differences when actors from different national business systems interact together. Mutual awareness and appreciation promoted through globalization processes create de facto diversity and differences in norms, views, practices and so on. These differences are further exacerbated by the highly uneven nature of globalization processes. Territorial differences and geographical unevenness remain central to globalization processes. To compete successfully in the global economy, actors in different business systems try to interpret each other's 'best practices' and incorporate strategically these practices in their own firm-specific routines and organizational processes. This transfer of 'best practices' between firms in different business systems, however, is highly problematic because of highly differentiated contexts. Even in the most celebrated example of such spatial transfer of 'best practices' (e.g. Japanese automobile transplants in the USA; see Mair et al., 1988; Kenny and Florida, 1993), there are serious limitations on how far these 'practices' can work in different business systems (see also Gertler, 1995).

Actors in firms also engage in significant efforts to outdo each other through continuous innovations and changes. This iterative process of organizational adaptation and change defines the dialectics of 
globalization because it both creates homogenization of business systems at certain points in time and space, and reinforces their continual differences at other points. It is not possible to specify a priori a singular logic and power relation for such interaction between the dialectical imperatives of homogenization and differentiation. This is because the realization of such dialectical tendencies depends very much on pre-existing trajectories and legacies of organizational patterns and the contexts of change. Since these organizational trajectories are highly institutionalized in specific territorial formations (e.g. in a nation-state), their scales and scopes of change are differentiated, at an abstract level, through spatial relations between capital and state. In addition, the contexts of change vary from one business system to another. This variability in contexts complicates the specification of the timing of change. The outcome of such a dialectical analysis of globalization tendencies is that we have to pay special attention to historically and geographically specific processes that account for organizational change and the dynamics of business systems. To sum up, the dynamics of a business system depends not just on the endurance of its social organization and institutional structures, but equally importantly on the dialectics of globalization tendencies. How then do globalization tendencies influence the configurations and dynamics of a business system? This is the analytical question for the next section on Asian business systems.

\section{THE IMPACT OF GLOBALIZATION ON THE CHANGING CONFIGURATIONS AND DYNAMICS OF BUSINESS SYSTEMS IN ASIA}

In this section, I consider the impact of globalization on Asian business systems. My aim is not to discuss exhaustively the various empirical dimensions of this impact. Rather, I aim to focus on how globalization has altered the central dynamics of Asian business systems by providing some mechanisms through which key actors in these business systems can be strategically enrolled into networks at different spatial scales (particularly the global scale). This enrolment into global actor networks implies that there are now qualitatively different linkages established between actors in Asian business systems and their counterparts in other business systems. These linkages enable more intensive flows of knowledge, information, capital and people between different business systems. Although this process may not necessarily lead to the emergence of dominant cross-national forms of economic organization (see Gereffi, 1996; cf. Whitley, 1996, 1998; Hollingsworth, 1998), I believe the changing dynamics of Asian business system facilitated by globalization tendencies has important implications for our understanding of the dominant forms and organization of Asian business systems. 
Through participation in globalization, key actors in Asian business systems are confronted with the past legacies of their domestic social and institutional structures. Although these domestic structures evolve slowly and are resistant to changes - no doubt a feature of institutionalization and past legacies - social actors in Asian business systems are much more receptive to changes and transformations brought about by globalization tendencies. These actors are also the key catalysts for eventual transformations in the social and institutional foundations of Asian business systems. As Castells (1989: 170) noted, 'the more organizations depend, ultimately, upon [global] flows and networks, the less they are influenced by the social contexts associated with the places of their location'. In a globalizing era, access to global networks becomes a basic condition for superior performance of most business organizations. It also takes precedence over any other influence from a particular location or business system. To examine this process of changing dynamics, I first consider the existing configurations of Asian business systems and then explore the interrelationships between globalization tendencies and the changing dynamics of Asian business systems. This is followed by an examination of the impact of globalization on the dominant forms and organization of Asian business systems.

\section{Existing configurations of Asian business systems}

The nature of Asian business systems has already received significant attention in the literature (Whitley, 1992; see also Redding, 1990; Hamilton, 1991; Gerlach, 1992; East Asia Analytical Unit, 1995; Weidenbaum and Hughes, 1996; Orrù et al., 1997; Chu and Wu, 1998; McNamara, 1999; Richter, 1999). Instead of reviewing comprehensively the entire configuration of Asian business systems (see Yeung, 2000c), I intend to summarize briefly here several key, but empirically differentiated, characteristics of national economies in Asia: (1) formation of intra- and inter-firm business networks; (2) reliance on personal relationships; and (3) strong state-business relations. It must be noted that these characteristics do not refer to a commonality that draws these Asian economies together. Rather, they refer to multiple configurations of dominant forms of business organization and institutional structures in Asia. As will be argued in the next sub-section, these three dimensions of Asian business systems can be significantly reconfigured through the participation of their key actors in globalization.

One of the best-known attributes of Chinese business systems is the important role and extensive influence of business networks or 'bamboo networks' (Hamilton, 1991; Weidenbaum and Hughes, 1996; Yeung, 1998c; Douw et al., 1999; Yeung and Olds, 2000). Personal relationships or guanxi are among the most important mechanisms to implement 
cooperative strategies in Chinese business networks, although their importance obviously changes over time and differs by geographical and sectoral (e.g. property) contexts (see Guthrie, 1998; Tsang, 1998). Chinese family firms in Hong Kong, for example, are the archetypal example of Chinese business systems. Their origins are complex, but can be broadly linked to cultural factors (Wong, 1988; Wang and Wong, 1997; Chiu, 1998) and colonial state practices (Sit and Wong, 1989; Chiu et al., 1997; Eng, 1997; Enright et al., 1997; Yeung, 2000d). The reliance on personal relationships, however, is not restricted exclusively to the practice of the ethnic Chinese only (e.g. Björkman and Kock, 1995; Lane and Bachmann, 1996, 1998; Windolf and Beyer, 1996). Hodder (1996: 52), for example, argues that "Guanxi (or reciprocity) is not a "thing", or "variable" or "channel". It does not characterize "the Chinese", nor is it part of a cultural mantle by which individuals can be identified as Chinese' (see also Nathan, 1993; Dirlik, 1997; Ong and Nonini, 1997; Yao, 1997). Different institutional systems may therefore create similar inter-firm relationships. Cooperative relationships in Chinese business systems, however, are largely embedded in personalized business networks, whereas their western counterparts tend to enter into cooperative relationships based upon firm-specific business strategies. Interpersonal relationships continue to serve as the foundation of cooperative relationships in Chinese business networks (Yeung, 1997a, 1997b).

On the other hand, it is important to stress the role of the state and its apparatus in constructing Asian business systems. This perspective originates from the developmental state literature which first made its impact in development studies during the early 1980s (Johnson, 1982, 1995; Deyo, 1987; Amsden, 1989; Wade, 1990). In much of this literature, the empirical focus is on how the state in Japan and several of the Asian newly industrialized economies (South Korea, Singapore and Taiwan) has actively and directly shaped national developmental trajectories through the establishment of economic planning agencies, the pursuit of strategic industrial policy, and the promotion of 'national champions'. These national champions are private firms in highly promising industries and sectors. They are strongly encouraged by the state through loans, grants and subsidies, monopoly rights, tax holidays and import protection. The inevitable outcome of this strong involvement of the state in national development is the formation of strong state-business relations.

In South Korea, the dominance of the chaebol in domestic business owes much to the support of its authoritarian regimes rather than to strong inter-firm relationships, as in the case of the Japanese keiretsu (Kim, 1997; Lee, 1997; McNamara, 1999; Steers, 1999). Some of them have become formidable competitors in the global economy (van Hoesel, 1999; Yeung, 1999c). In Japan, the keiretsu are not as dominating in Japan's industrial organization as their counterparts from South Korea. Gerlach 
(1992) shows that much of the keiretsu's dynamics originates from their internal strength rather than from state support per se. While the keiretsu have played a very important role in the formation of regional production networks, Japanese firms rely heavily on these keiretsu networks for access to the global market rather than for access to local suppliers (see also Tsui-Auch, 1999; Aoyama, 2000). In Taiwan, the state-business relationship evolves from a family-centred industrial organization to one in which large firms have much better access to state resources and subsidies (see Mathews, 1997 and Mathews and Cho, 1998 for an example from the semiconductor industry). Faced with the lack of competitiveness vis-à-vis large firms, small- and medium-sized Taiwanese firms have to lever their strategic advantages of flexibility and adaptability through informal networks and subcontracting relationships (Buck, 2000). Some of these small firms have even brought their networks across national borders into China (Hsing, 1998) and South-East Asia (T. J. Chen, 1998).

In South-East Asia, the case of Singapore points to a radically different empirical situation whereby the developmental state has actively developed the island economy into a major node in the global spaces of flows (Rodan, 1989; Perry et al., 1997; Low, 1998; Yeung and Olds, 1998). Instead of developing industrial networks constituted exclusively by local firms, the state favours the development and deepening of global-local linkages through which Singapore can gain from the influx of foreign high-technology investments (see Brown, 1998; Perry and Tan, 1998 for a case study of Singapore's electronics industry). The state is also highly active in developing an 'external wing' for the national economy through the regionalization of domestic firms. This process of outward orientation of the national economy has again been spearheaded by statutory boards and government-linked companies (Yeung, 1998d, 1999d, 2000d). The unique configuration of state-business relationships in Singapore, a predominantly Chinese society, provides an institutional foundation for the emergence of a business system significantly different from a typical Chinese business system (e.g. Hong Kong).

In other South-East Asian countries, it appears that political-economic alliances based on patron-client relationships have taken precedence over state-driven industrial and business networks in these still developing economies. This preference for political connections is particularly important in the context of the state's ethnic-biased redistribution economic policies through which indigenous capitalists (known as pribumi in Indonesia and bumiputra in Malaysia) have been given special rights and privileges. An institutional outcome is the rise of the so-called ersatz capitalism in these South-East Asian economies (Yoshihara, 1988; McVey, 1992; Yeung, 1999a, 2000b). In this case, Chinese business systems have embedded themselves in the political-economic alliances of the host South-East Asian countries. Whereas some ethnic Chinese have 
consolidated and strengthened their intra-ethnic group networks to overcome hostile business and institutional constraints in the host countries, other more pragmatic ethnic Chinese have engaged in patron-client relationships with indigenous South-East Asian capitalists. This process of 'network juxtaposition' has resulted in a hybrid network structure in South-East Asia, comprising family networks and political-economic alliances. Still, other ethnic Chinese have chosen an 'exit strategy' by internationalizing their business operations into other parts of Asia and beyond. In their internationalization processes, these ethnic Chinese from South-East Asia have once again leveraged on their transnational networks of personal and business relationships (Yeung, 1998e, 1999b; Yeung and Olds, 2000).

\section{Changing dynamics of Asian business systems}

It is far to claim that there are significant transformations in the institutional governance and organizational structures of the global economy today. Even though they may not fundamentally reconfigure national business systems, globalization tendencies have at least made apparent multiple possibilities and opportunities through actors' enrolment and participation in globalization. This increasing awareness of globalization tendencies is particularly important for key actors and elites in Asian business systems who are being enrolled into global actor networks and thereby are connected to different business systems. From an evolutionary perspective, these emerging changes can lead to further dynamic changes in the social organization and institutional structures of business systems if the 'equilibrium' of existing parameters is disrupted by sudden and unexpected events. In the case of Asian business systems under globalization, certain emerging changes at the level of key actors may disrupt the 'equilibrium' of these business systems. This disruption of pre-existing orders of Asian business systems was particularly apparent during and after the recent 1997 Asian economic crisis (see also Baer et al., 1999; Henderson, 1999). Before considering the impact of globalization on the dominant forms and organization of Asian business systems, I first examine the changing dynamics of Asian business systems by focusing on the enrolment of Asian actors into global actor networks.

The theoretical underpinning of this sub-section draws upon actor network theory following Michel Callon, Bruno Latour and John Law. Actor network theory has gained increasing currency in the social sciences because it is seen 'as a useful way of thinking about how spatial relations come to be wrapped up into complex networks' (Murdoch, 1999: 357; see also Thrift, 1996, 1999a; Murdoch, 1997; Whatmore, 1997; Parry, 1998; Hassard et al., 1999). It is a useful approach to network 
research because it offers 'a non-dualistic standpoint by focusing on how things are "stitched together" across divisions and distinctions" (Murdoch, 1997: 322). The main claim of actor network theory is that actors and their intermediaries from spatially disparate places are enrolled into networks of heterogeneous association and relations. The ability of actors to reach across space and 'act from a distance' ultimately depends upon involving other actors and the necessary material objects, codes, procedural frameworks and so on that are required to effect the activation of power. A fundamental part of extended network construction is the ability to create and manage the knowledge, vocabulary, procedures, rules and technologies through which economic activity is conducted. A good example is the globalization of accountancy standards that allows financial management from a distance (Sassen, 1999) or the development of standards on which financial information publiclisted corporations must release to shareholders and the public. The creation, legitimization and adoption of such knowledge, rules and so on generate power for some actors in networks because they are effectively able to reshape the strategy and activities of other actors in networks (Thrift, 1998, 1999a). To a certain extent, these social actors are synonymous with 'elites' bound by strong social, professional or political ties (Parry, 1998; Woods, 1998).

Actor network theory is useful for understanding and analysing the dynamics of Asian business systems for several reasons. First and most importantly, it allows us to understand the spatiality of networks constructed by social actors in Asian business systems. The comparative institutional analysis of Asian business systems has focused excessively on their internal structures and overlooked how these structures can be related to wider political-economic dynamics in the global economy. As argued above, globalization tendencies operate at a spatial scale beyond individual nation-states and national business systems. To understand how these globalization tendencies impact upon the internal dynamics of these national institutional structures and business systems, it is necessary to appreciate the complex ways through which actors from different business systems and disparate places are enrolled into networks of heterogeneous association. Second, mapping actor networks allows us to appreciate better the creation, legitimization and adoption of power, knowledge and rules beyond specific business systems. These intangible flows in the global economy are important in shaping the strategies and behaviour of key actors in national business systems. As shown below, key actors in Asian business systems have deliberately gone beyond their national knowledge structures by enrolling into global actor networks. Through this transfer of knowledge and practices on a global scale, actor networks provide the necessary impetus for key actors in Asian business systems to effect changes and transformations in their home 
countries. Finally, actor network theory is self-evidently a methodology focusing on individual actors and their networks of heterogeneous relations. It is a bottom-up approach to understanding globalization tendencies and their impact on national institutional structures and business systems. It is a good complementary analytical framework for us to understand the dynamics of Asian business systems.

How then are key actors from Asian business systems enrolled into and influenced by global networks elsewhere? These actors are defined as political, social or business elites who are capable of effecting institutional changes at the national level. There are at least four interrelated mechanisms through which this enrolment into global actor networks is made possible: (1) engaging with global managers and financiers in international business and finance; (2) participating in international media and research on business activities; (3) gathering knowledge and experience through international educational institutions; and (4) connecting with international organizations and multilateral institutions. Although these mechanisms are by no means equal in their importance, it is hard to ascertain their relative importance in the absence of comprehensive empirical studies. I believe that the first two mechanisms are particularly relevant to the strategic behaviour of Asian firms, whereas the remaining two mechanisms are important to Asian elites in gaining access to knowledge elsewhere and in legitimizing their political power and dominance in their home countries. This differential importance becomes clearer when I discuss the impact of globalization tendencies on Asian business systems.

In the first place, the emergence of Asia as a major global economic powerhouse is linked to both the globalization of non-Asian firms into Asia and the globalization of Asian firms into non-Asian host countries. Though Whitley $(1996,1998)$ argues that the consequences of these globalization tendencies for national business systems and firms are limited, it is by no means clear that these limited effects of globalization do not represent a long-term process of changing dynamics of Asian business systems. In particular, the two-way globalization of firms between Asia and other regions implies that key actors in Asian business systems are compelled to learn new management and business practices from their competitors, suppliers, customers and so on. At the same time, these same actors need to undo some of their previous learning and practices in order to compete effectively against their foreign counterparts in Asia as well as on their home turf. It is true that this process of business contacts between east and west occurred long before (e.g. during Meiji Japan in the mid-nineteenth century; see Westney, 1987, Hamilton, 1997). But the sheer scale, scope and speed of these contacts today make them highly influential in the changing dynamics of Asian business systems. 
This process of organizational learning through international business and international finance occurs in several ways. Asian actors may appoint non-Asian actors to manage their operations both in Asia and in host countries outside Asia. A good example is the recent appointment of John Olds (a former banker with Merrill Lynch and J. P. Morgan) to be vice-chairman and CEO of Singapore's largest bank - the governmentlinked Development Bank of Singapore. These global managers are often endowed with significant experience in managing transnational operations in national economies with distinctive business systems. Their involvement in Asian firms may reshape the norms and practices in these organizations (e.g. see Reich, 1991, for the case of Sony; Mair, 1994, for the case of Honda). Asian actors may also pick up organizational knowledge and practices in non-Asian host countries through transnational operations (e.g. see Mathews and Snow, 1998, for the case of Acer from Taiwan; Yeung, 1999c, for a collection of mostly empirical studies of Asian firms in North America and Europe; Yeung and Olds, 2000, for another collection of some empirical studies of Chinese business firms from Asia in North America and Europe). These knowledges and practices can originate from their intensive interaction with customers and suppliers in the host countries or from their previous employment in foreign firms. Actor networks are formed between Asian actors and their customers, suppliers and competitors on a global scale, facilitating interpersonal information and knowledge flows and organizational adaptation. Examining the international human resource management practices of Singapore companies in China, Tsang (1999a, 1999b) recently found that expatriation has an important function of knowledge transfer and training.

On the other hand, actor networks in international finance represent one of the most influential mechanisms for effecting dynamic changes in Asian business systems. This is because for those Asian firms and/or countries in search of financial resources from outside their home countries and/or regions, it is important to secure the consent and recognition of global financiers for good governance and return to investments. These global financiers are leading bankers, fund managers and brokers. They are often based in major global cities that serve as their command centres of global investments (Sassen, 1991). The successful enrolment of Asian actors into these global financial actor networks is imperative in an era of more intensified competition, greater financial requirements for expansion and investments, and higher risks associated with excessive reliance on domestic finance. To ensure that global financial elites are comfortable with their financial positions and obligations, key actors in Asian firms/countries are required to follow certain accounting standards and business norms in global capital markets. This necessity for securing global finance provides a key force to effect dynamic changes in Asian 
business systems (see the case of Li Ka-shing below). The recent 1997/8 Asian economic crisis has made these changes even more apparent and necessary (see also Yeung, 1999a, 2000b, 2000e).

Second, this quest for global finance requires actors in Asian business systems to come to terms with actors in international media and research on business activities. This is because today's global financial system is increasingly characterized by a broader array of actors beyond just bankers and financiers (Harmes, 1998). As Thrift and Leyshon (1994: 301) argue, 'money, the international financial system, and international financial centers' have simple " "detraditionalized" over the last 30 years or so ... because of the breakdown of state authority and its replacement by more diffuse sources of governance' (my emphasis). Such detraditionalization is accentuated by the enormous task of understanding, managing and communicating about global economic change in a more reflexive manner. This is a style of understanding, managing and communicating that draws a broader array of actors into playing a significant (albeit variable) role in materially and discursively constructing the multiple economic systems that make up the global economy (Thrift, 1996; Hollingsworth, 1998). Actors in international media and research houses play an increasingly important role in producing reflexively texts and information about Asian business systems that can significantly hinder or facilitate Asian actors' access to global finance.

For example, top international financial newspapers (e.g. The Financial Times), magazines (e.g. Fortune) and media (e.g. CNN and CNBC), creditrating agencies (e.g. Standard and Poor's), stock-broking firms and other research houses (e.g. Morgan Stanley) regularly produce reports on Asian firms (and, sometimes, Asian economies). The 'consumers' of these texts are key actors in the global financial industry and international business, including investment bankers, fund managers, brokers and so on. Successfully persuading these global actors into favourable assessments of Asian firms requires these Asian actors to enrol themselves into global actor networks in international media and research activities. Not only are Asian firms participating in producing such texts (and counter-texts) through setting up their own credit-rating firms, stock-broking houses and so on, some of them are also opening their doors to welcome global actors to 'inspect' their operations. Such processes of enrolment and persuasion have major implications for the changing norms and practice of these Asian firms and, perhaps eventually, their national business systems.

Space limits allow me to cite just one example here. One of Asia's best-known ethnic Chinese patriarchs, Li Ka-shing, managed to restructure successfully his Cheung Kong Group (CKG) in Hong Kong in early 1997 by enrolling key actors in international business media and research houses into his business networks (see Olds and Yeung, 1999, for more 
detail). On 6 January 1997, writers representing global business media grappled with a complex proposal for the reorganization of Li's multibillion dollar corporate empire. His Cheung Kong Group had a total market capitalization value of $\mathrm{HK} \$ 433$ billion as of 15 April 1998 <http://www.ckh.com.hk/index2.htm>. A press release was faxed out without advance warning, though those 'in the know' would clearly have known what was developing in Li's corporate base (Hong Kong) for some time. The channels of gossip in Hong Kong's local business community are simply too quick and dense for John Ridding - one of The Financial Times' most influential and well-connected journalists - to have been caught unaware. Ridding's analysis (written with Louise Lucas), nearly three-quarters of a page long, was published one day later (7 January) in The Financial Times - the distinctive pinky orange pages of the world's financial elite. This daily newspaper plays a powerful role in disseminating and trading ideas at a variety of scales (from local to global) between three broadly defined communities - the firm, the investor and the fund manager. The Financial Times has a significant impact in contributing to (though not determining) the rapid formation of opinion in the world's financial centres about the potential effectiveness of the restructuring.

Global flows of information demand a global media strategy. Chinese business firms attempting to operate at a multitude of scales increasingly seek to draw upon economic resources via global capital flows, and they must therefore structure their activities to facilitate favourable business media coverage. Further, this media coverage must be handled by a small number of elite translators of economic knowledge (e.g. Asiamoney, Euromoney, The Financial Times). Developing a global media strategy is a practice subject to continual planning within the group, though usually in association with trusted public relations firms. It is also dependent upon the nurturing of effective social relations with key sources working within the global media sector. The formation of such relations is also a goal for representatives of global media since their business includes describing and analysing relevant information on the activities of highly capitalized Asian firms.

By 10 January 1997 (four days later), such global securities firms as Goldman Sachs, Morgan Stanley and Nomura released reports on the proposed organization of the CKG. These texts, semi-private texts, were speedily distributed around the world to qualified institutional buyers. Detailed analyses by experts based in Hong Kong were presented in the reports. Many different aspects of the restructuring process were evaluated. Assessments were made about the short- and long-term prospects for all four publicly listed members of the CKG. The benefits that can be generated by enrolling in global actor networks are obvious. In this case, the proposed restructuring was viewed favourably by international 
business. It consequently left Li Ka-Shing 'more firmly in control of his four listed companies, shifted value to his personal holdings and increased his group's market value by $£ 2$ billion in two days' ('Li KaShing's shuffle dazzles Hong Kong', The Sunday Times, 12 January 1997). The proposed restructuring was also expected to register 'exceptional gains' of HK\$1.9 billion for Hutchison Whampoa Ltd and HK $\$ 4.9$ billion for Cheung Kong Holidays in fiscal year 1997 (Goldman Sachs, 1997). Clearly, the willing enrolment of Chinese business elites in international business actor networks can open access to flows of significant financial resources. However, decisions over opening up access to flows of capital ultimately depend upon them proposing and implementing changes in business practices that are deemed rational and profitable according to financial analysts. As noted above, the majority of such changes entail moving towards more transparent business practices (including audited balance sheets) and decision-making authority. Given this situation, 'Chinese' business practices are effectively shaped by the criteria developed by financial analysts representing the gatekeepers of the global space of financial flows.

Third, a clear trend in today's Asian business systems is that most key actors in these systems have spent time during their educational life in institutions located in North America, Western Europe and Australia. Most significantly, the globalization of business knowledge is linked to the emergence and, perhaps, domination of top business schools located in North America and Western Europe (see Thrift, 1998, 1999b). Key actors in Asian family businesses now face the challenge of professionalizing their management and business practices. Other actors in Asia's non-family businesses are also active in organization reengineering and management restructuring to prepare for global competition. This process of professionalizing Asian capitalism(s) is driven both by internal and external factors. Internally, more patriarchs in Asian family firms have allowed their heir-apparent to be educated in top business schools abroad. Exposed to professional management training in these business schools, on their return these successors to Asian family businesses contribute to the changing dynamics of Asian business systems in two ways. On the one hand, personal contacts and relationships developed by these successors abroad potentially widen the social and geographic scope of 'Asian' business networks when external nonAsian members are 'brought' or socialized into 'Asian' business networks. Key Asian actors thus not only are enrolled into global financial actor networks with their friends and acquaintances from business schools, but also sometimes actively entice these actors into their own networks in Asia. This process of enrolment and enticement implies that the concept of exclusive Asian business networks should be broadened to a large degree to include non-family and non-Asian members (e.g. 
see Mitchell, 1995, and Olds, 1998, for the case of ethnic Chinese investments in Vancouver).

On the other hand, the return of a professionally trained family heir represents an important step towards the professionalization of Asian business. When the heir eventually takes over the family business, he/she tends to adopt a much more open view towards the involvement of professionals in the management of the family firm (e.g. see Fung, 1997; Magretta, 1998, for the case of Victor Fung from Hong Kong's Li \& Fung). This is certainly not the same phenomenon as predicted in the existing literature on Asian family firms where paternalism, nepotism, personalism and fragmentation are widely believed to be the key characteristics of their organizational rigidities (e.g. Redding, 1990; Chen, 1995; Fukuyama, 1995; cf. Yeung, 2000a).

Fourth, Asian elites are now more connected with international organizations and multilateral institutions than ever. These powerful supra-national economic organizations and financial institutions include the IMF, World Bank, OECD, APEC, UNCTAD and so on. These are institutions that engage in private and public debate over economic reform at a national and sectoral level and occasionally participate in the development of specific economic restructuring programmes in the Asia-Pacific region. Representatives of multilateral institutions implement diffuse forms of governance that have significant effects in shaping the business practices of Asian firms, in particular through recommendations (and implementation pressure) on the systemic reform of nationally regulated financial systems (including banking and stock markets). Multilateral institutions, such as the IMF, are able to reshape Asian business systems in a thorough but diffuse manner by encouraging and/or requiring the restructuring of institutions and power structures in Asia with which large Asian businesses (especially the conglomerates) engage in reciprocal relations of interdependence. By involving other actors (the nation-state) and the necessary codes, procedural frameworks, regulations, material incentives and so on that are required to effect the activation of power, multilateral institutions directly and indirectly transform the nature and operation of Asian business systems (see the example of South Korea later).

These dynamic changes to Asian business systems brought about by international organizations, however, cannot be effective without the consent and involvement of Asian elites. Here, the issue of power relations becomes paramount because any significant changes to the existing configurations of Asian business systems imply a concomitant demise of certain interest groups (e.g. cronies and rent seekers) and the emergence of other groups (e.g. supporters of democracy and transparency). Why then would key actors in Asia participate and enrol in these actor networks of multilateral institutions? Some Asian actors are clearly 
opportunists who participate in these global actor networks in order to ride on the same 'wave' and secure their own legitimacy in business and politics. Other Asian actors find the past legacies of Asian business systems make it virtually impossible to transform them without significant external pressures. Enrolling into global actor networks helps these Asian actors to advance their ideas of reforming and transforming domestic business systems (see below). The last group of Asian actors enrols into networks of international organizations to promote global understanding and interaction. It is unlikely that this would lead to the demise of national business systems in favour of a new cross-national economic coordination system. What is clear, however, is that this process of enrolling Asian actors into the global networks of international organizations and multilateral institutions has a potential long-term impact on the dominant forms and organizations of Asian business systems.

\section{Impact of globalization on the dominant forms and organization of Asian business systems}

In this section, I consider the possible impact of globalization tendencies on two aspects of Asian business systems: (1) governance structures and authority systems of national firms; (2) market organization and political-economic structures. In the first place, globalization tendencies are transforming the governance structures and authority systems of national firms in Asian business systems. There is a significant shift from paternalistic governance of Asian firms based on personal relationships and owner management to network governance based on decentralization, financial performance and board decisions. This shift depends on the geographical scale and scope of Asian firms and their actor networks. As shown in Figure 1, there are at least three types of actor networks among Asian firms: global networks, national networks and national/ international networks. For heuristic purposes, each bounded circle in Figure 1 represents a relatively distinct business system and each point in these circles represents an actor (economic or political). Through linkages developed by globalization tendencies, these actors in different business systems are enrolled into actor networks at different spatial scales and complexities.

Take actor A, for example: it is enrolled into global networks directly with actors in all other business systems and indirectly with actors in two business systems via actor D. Its network relationship with actor D is at the national level with a primary aim to reach out to actor D's global networks. This relationship forms part of what is known as national/international actor networks. Actor A represents the most globalized actor in Figure 1; so is its business system which bears a mixture of characteristics of different business systems. In the case of 


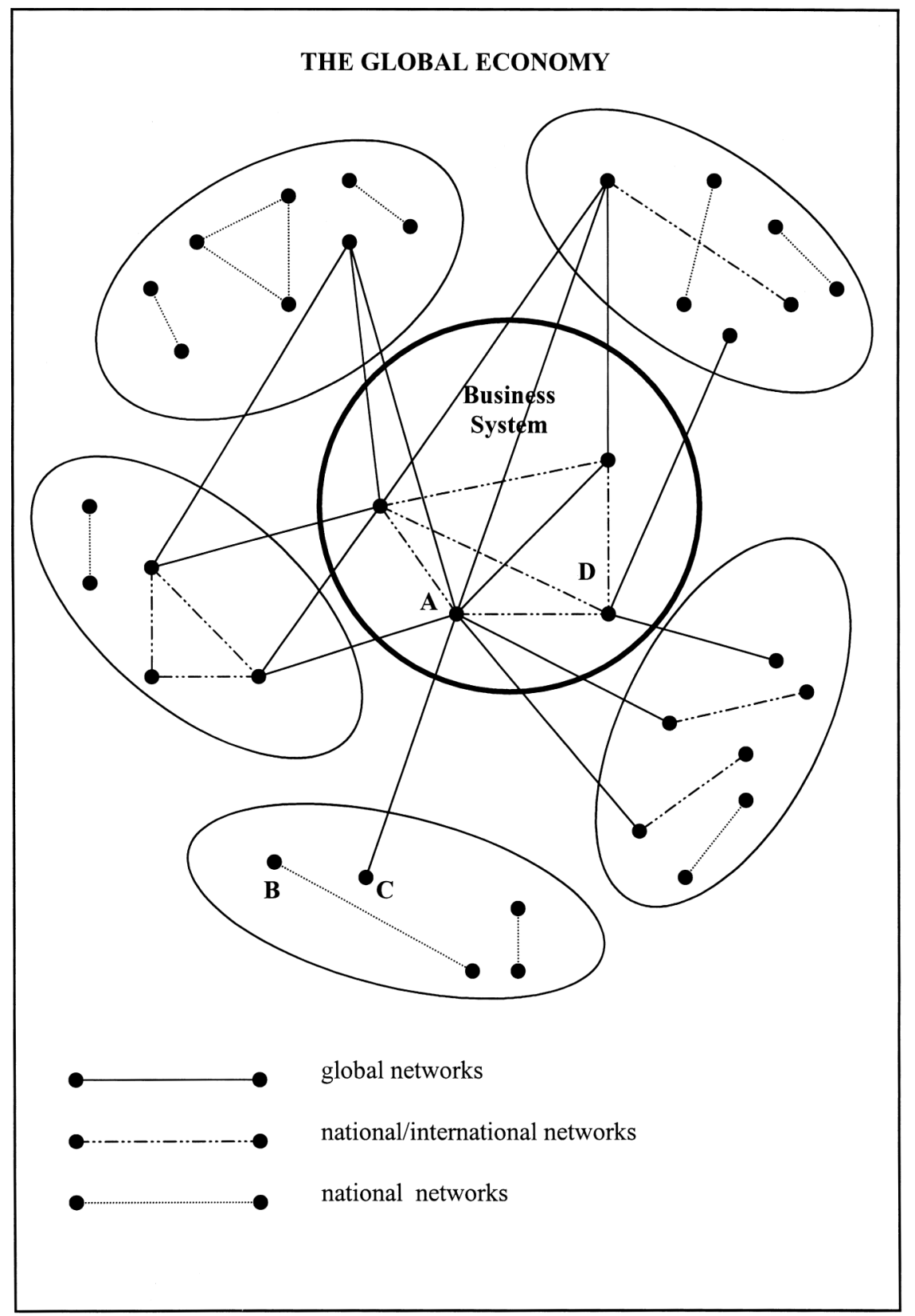

actor B (e.g. a local retailer), it is primarily enrolled into national actor networks and remains very much embedded in national business systems. On the other hand, actor $C$ is enrolled exclusively into global networks (e.g. an export-oriented manufacturer serving the global 
market). Though Figure 1 is a much simplified construction of the nature and characteristics of Asian business systems, it does illustrate the very important point that globalization tendencies (represented by various links between actors) are capable of effecting dynamic changes to existing business systems. As a consequence of these inter-penetrating tendencies, the empirical reality of any Asian business system is made up of a mosaic of characteristics from several other business systems. Influenced by globalization tendencies, Asian business systems are much more messy in their dominant forms and organizational structures than are portrayed in the literature.

The shift towards network governance structures is most pronounced among Asian firms that are enrolled into global actor networks. These Asian firms are more likely to be very active in globalizing their operations. They are also more likely to invoke and implement organizational changes because of two reasons. First, the paternalistic governance structure creates formidable organizational obstacles to successful globalization because of centralization of control and information, and the replication of headquarters characteristics in foreign subsidiaries. Globalizing Asian firms may find it difficult to develop new sources of ownership-specific advantages in non-Asian host countries because rules of competition there are much more transparent and established. Paternalism is not very conducive to unleashing the potential and entrepreneurial tendencies of local managers in these host countries. A shift towards network governance is possible when key actors in these Asian firms realize the potential of enrolling into actor networks in host countries (e.g. recruiting top management from the host countries). This transformation in governance allows Asian firms to tap into synergies of 'differentiated networks' because diverse subsidiaries operate in distinct national environments (Nohria and Ghoshal, 1997). Different attributes of a globalizing Asian firm can be explained in terms of selected attributes of the external network within which it is embedded. These differences in the external network are related to the institutional context of the globalizing Asian firm.

Second, globalization tendencies are beginning to transform domestic institutional contexts in which paternalistic governance structures are embedded. As the market organization and political-economic structures in Asia are changing gradually (see below), the monopolistic advantage and/or state subsidies often enjoyed by some typical Asian firms dissipate rather quickly. Globalization tendencies are changing the rules of the game in Asia in favour of competence-based competition rather than the monopolistic competition that prevailed during the early phase of Asia's industrialization. This revision of competitive rules and institutional contexts implies that paternalistic governance structures of Asian firms are no longer very effective in securing and accumulating 
resources for expansion (see Yeung, 1999a, 1999b, 2000b, for the case of the South-East Asian countries). It becomes important for these Asian firms and their key actors to develop competitive advantages based on organizational competence rather than on monopolistic licences or political favours. I am not arguing that these latter advantages will disappear overnight. Such an argument is over-simplistic and unrealistic. I argue, however, that key actors in Asian firms, particularly those enrolled into global actor networks, are pre-emptive of the transformation of domestic institutional contexts and the arrival of global competition. They are more susceptible to organizational change towards a governance structure based on their enrolment into global actor networks. Their performance and successes are more dependent on their linkages to other actors in global networks than on their domestic institutional structures.

How then are the market organization and political-economic structures in Asia transformed by globalization tendencies that have significant implications for the dynamics of Asian business systems? This is a complex question that I can only discuss briefly here. As outlined earlier, the market organization of most Asian economies is dominated by strong state-business relations explained by the historical legacies and institutional structures of Asian economies (see Whitley, 1992, 1999). The dialectical tendencies of globalization, however, seriously disturb this relatively stable configuration of 'institutional equilibrium' in many Asian economies. On the one hand, the enrolment of key Asian elites into global actor networks has enabled them to construct certain political discourses to legitimize their reform agendas. Privatization and deregulation are some of the reform efforts institutionalized by Asian political elites to embrace the benefits of participating in globalization (e.g. Singapore's recent liberalization of the banking and telecommunications industries). These efforts are likely to generate long-term impacts on the dominant forms and organization of Asian business systems. For example, the 1997/8 Asian economic crisis provided such a context for change and reforming Asian business systems (see also Henderson, 1999; Yeung, 1999a, 2000b). Some powerful domestic elites within Asia have been quick to jump on the globalization bandwagon to pursue their own hidden agendas of implementing structural reforms and building institutional capacities, which otherwise could not be pursued without an 'externally imposed' necessity to do so. In effect, the (contested) discourse of globalization 'itself has become a political force, helping to create the institutional realities it purportedly merely describes' (Piven, 1995: 8).

The case of South Korea shows how a careful deconstruction of an Asian identity enables political elites to shape the restructuring initiatives. In South Korea, the IMF rescue package represents three agendas at work: a conventional IMF agenda, a US trade- and investment-opening agenda, and a Korean-imposed institutional reform agenda (Mathews, 
1998; see also Wade and Veneroso, 1998). The first two agendas are clearly interrelated and not widely accepted by the Koreans. Bello (1998: 425) thus notes that

the Fund is very unpopular [in South Korea], not only because it is seen as administering the wrong medicine, but because it is viewed as a surrogate for the USA, imposing a program of deregulation and liberalization in trade, investment and finance that Washington had been pushing on the country - with little success - before the outbreak of the financial crisis.

In fact, as the US Deputy Treasury Secretary Lawrence Summers said, 'the IMF has done more to promote America's trade and investment agenda in Korea than 30 years of bilateral trade talks' (quoted in Hale, 1998: 12). The third agenda, however, has been so rigorously pursued by the political elites in South Korea that

by the middle of 1998 [South Korea] was rebuilding a new version of a 'Korean model' - turning the crisis to its own advantage by reforming the political-economic structures, which were in fact long overdue for reform but which could not be tampered with in the absence of a major crisis.

(Mathews, 1998: 748)

What exactly did the Korean elites make of the heavy-handed IMF intervention in December 1997 which was certainly not the first time that Korea had fallen into the IMF's grasp (previous occasions were in 1971 and 1980-3)? The 'old' Korean model of rapid economic development was based on high foreign debt for expanding industrial capacity and large chaebol for steering the national economy. The role of state agencies in directing development was also very important (Amsden, 1989; Wade, 1990; Kim, 1997; Lee, 1997; Chang, 1998, 2000; cf. Thornton, 1998). Such a model sustained South Korea's high growth rates during the 1980s. By the 1990s, the model was sustained by taking on risks on a larger scale and by depending on continuously favourable global economic conditions. Just before the crisis, the model was becoming so powerful that it began to be a threatening political force beyond the control of existing state agencies and newly created democratic institutions. It could only be 'stopped' by a major crisis (Mathews, 1998). The unravelling of the Korean model in late 1997, therefore, witnessed the Korean elites, led by the Kim Dae-Jung administration, taking the extraordinary opportunity created by IMF intervention to transform the Korean model from a developmental system to a 'more mature' business system. According to Mathews (1998), these Korean elites from the various government ministries indeed instigated structural reforms into the IMF agreement rather than being forced to concede to such reforms, as in the case of Indonesia. These reforms 
covered matters such as (1) greater transparency in corporate governance and structure; (2) reducing the levels of mutual debt repayment guarantees; (3) opening the way to corporate bankruptcy procedures; and (4) reform of the financial sector, including the separation of the Bank of Korea from the Ministry of Finance.

This response by the South Korean political elites to the Asian economic crisis and the IMF conditionality is in fact interesting. It is clear that these domestic political elites wanted institutional changes and reforms of their business systems. In the absence of strong political power and discursive legitimacy, they were unable to implement these changes and reforms. This reform inertia reflected the significant role of historical legacies and institutional rigidities. For example, it is well known that the chaebol in South Korea did not want to see the end of their cosy relationships with the government and ministries. Given their dominant corporate power in South Korea, the state found it very difficult to plan for, let alone implement, changes to state-business relationships. Meanwhile, the unexpected outbreak of the Asian economic crisis provided a favourable context for change. The enrolment of some political elites in South Korea into global actor networks (e.g. the IMF and NGOs for democratic movements) enabled them to construct discursive legitimacy to justify their reforms. The case of South Korea is also not atypical. During the Asian economic crisis, the Washington-based IMF was also successful in effecting change in state-business relationships in Indonesia at a distance. For example, Mohammad 'Bob' Hasan, a leading actor in local Chinese business networks, lost his valuable monopoly rights in timber production and trade in Indonesia (see Olds and Yeung, 1999).

\section{CONCLUSION}

While I concur that the enduring properties of different social systems of production and national institutional structures continue to reinforce differences in national business systems (see also Hollingsworth, 1998; Whitley, 1998, 1999), globalization tendencies have a significant impact on the dynamics of these business systems. This impact is particularly effective at the level of key actors and elites in these business systems because they have been enrolled and enticed into various forms of actor networks at different spatial scales. Through their connections with actors in international business, finance, media, research, education and multilateral institutions, Asian actors and elites are increasingly capable of effecting changes in existing norms, conventions and practices of Asian business systems. In other words, globalization tendencies provide the key mechanism through which the dynamics of Asian business systems can be unleashed and their existing configurations reshaped and transformed. These tendencies also alter drastically the institutional contexts 
in which the stability and endurance of Asian business systems are maintained.

Though the transformations of Asian business systems under globalization are conditioned by past histories and institutional legacies, the specific directions and modes of transformations depend critically upon the dialectics of globalization tendencies, and the nature and spatial scales of Asian actors being enrolled into actor networks elsewhere. I have argued in this article that globalization tendencies are not merely homogenizing national differences in social organization and institutional structures, but they also simultaneously accentuate material and discursive differences, a consequence of their highly uneven nature and impact. Most debates in globalization studies are clearly misconceived because of their focus on the dichotomous choice of homogenization or differentiation. To understand the changing dynamics of Asian business systems in a globalizing era, it becomes imperative for us to transcend this dichotomous view of globalization. We need to examine how the dialectical tendencies of globalization can be deployed by Asian actors and elites, who are enrolled into actor networks at different spatial scales, to effect changes in the norms, conventions and practices of their embedded business systems.

This article clearly represents an unfinished agenda because it raises more questions than it can answer. I now consider two critical agendas for future research into different business systems as dominant forms of organizing capitalism(s) in the global economy of the new millennium (see also Whitley, 1996): (1) focus on dynamic rather than static differences in business systems; and (2) focus on transformations of business systems at different spatial scales. First, it is apparent from this article that the central issue in understanding any business system is not how it is different from an existing template of, say, the American, German or Japanese business system. Though these national differences in business systems may exist, they are often subject to dynamic changes over time. This is essentially a process of co-evolution through which different business systems may converge in certain dimensions and diverge in other attributes. It is thus important for researchers of business systems to focus on the critical agent(5) of dynamic change rather than static structural differences between business systems. Here, globalization tendencies and actor networks may provide a useful theoretical departure point to analyse the changing dynamics of business systems in different countries and/or regions. We need more empirical studies to disentangle the complex relationships between such globalization tendencies and the dynamics of different business systems. Instead of conceiving national business systems as a 'static equilibrium', we should view them as a 'dynamic equilibrium' or at best a 'partial equilibrium' which is always in flux and subject to change (see also Sorge, 1996). Our 
research task is to identify their agents of change (e.g. globalization tendencies) and their mechanisms of transformations (e.g. actor networks).

Second, while the economic coordination and social organization of activities in many business systems have been almost exclusively confined to the national or sub-national scale in the past, the new millennium will witness the diffusion of this coordination and organization to multiple spatial scales (see also Hollingsworth, 1998; Collinge, 1999; Kelly, 1999). To critical theorists like Jessop (1999), such a process of rearranging the spatial scales of economic coordination in an era of globalization is known as the 'relativization of scale'. The expanding orbit of the political, social and economic influence of the European Union and the recent powerful penetration of IMF-driven politics into certain Asian economies are just two examples of economic coordination at the regional and the global scales. Similarly, Figure 1 notes that linkages between actors in different business systems are increasingly formed at different spatial scales. Future empirical research should perhaps move away from starting its analysis at the national scale. Instead, the future of business system research rests with how best we can transcend different spatial scales in our analysis of the dynamic transformations of business systems. This quest for analysing business systems from the perspective of different spatial scales has a strong potential to enrich our understanding of the tensions between globalization tendencies and social systems of economic organization.

\section{ACKNOWLEDGEMENT}

This article benefits from an ongoing research project funded by the National University of Singapore (RP970013). An earlier and longer version was presented at the International Research Conference on 'Business in Development: Local Companies Between Social Embeddedness and Globalization', Copenhagen Business School, Copenhagen, 18-19 November 1999, and a seminar hosted by the Department of Business Studies, Uppsala University, Sweden. I would like to thank Anders Malmberg, Peter Dicken, Michael Morris, Rajah Rasiah, Kerstin Sahlin-Andersson, Deo Sharma, Henrik SchaumburgMüller, Olav Jull Sørensen and Peter Wad for their helpful and constructive comments. Similarly, very useful comments from three RIPE reviewers are gratefully acknowledged. None of these institutions or individuals should be responsible for any errors or mistakes.

\section{REFERENCES}

Amsden, Alice (1989) Asia's Next Giant: South Korea and Late Industrialization, New York: Oxford University Press. 
Aoyama, Yuko (2000) 'Networks, keiretsu and locations of the Japanese electronics industry in Asia', Environment and Planning A 32(2): 223-44.

Backman, Michael (1999) Asian Eclipse: Exposing the Dark Side of Business in Asia, Singapore: John Wiley.

Baer, Werner, Miles, William R. and Moran, Allen B. (1999) 'The end of the Asian myth: why were the experts fooled?', World Development 27(10): 1735-47.

Beamish, Paul W. and Killing, J. Peter (eds) (1997) Cooperative Strategies, 3 vols, San Francisco, Calif.: The New Lexington Press.

Bello, Walder (1998) 'East Asia: on the eve of the great transformation?', Review of International Political Economy 5(3): 424-44.

Berger, Suzanne and Dore, Ronald (eds) (1996) National Diversity and Global Capitalism, Ithaca, NY: Cornell University Press.

Best, Michael H. (1990) The New Competition: Institutions of Industrial Restructuring, Cambridge: Polity Press.

Björkman, Ingmar and Kock, Sören (1995) 'Social relationships and business networks: the case of Western companies in China', International Business Review 4(4): 519-35.

Brown, Ross (1998) 'Electronics foreign direct investment in Singapore: a study of local linkages in "Winchester City"', European Business Review 98(4): 196-210.

Buck, Daniel (2000) 'Growth, disintegration, and decentralization: the construction of Taiwan's industrial networks', Environment and Planning A 32(2): 245-62.

Buckley, Peter J. (ed.) (1994) Cooperative Forms of Transnational Corporation Activity, United Nations Library on Transnational Corporations 13, London: Routledge.

Castells, Manuel (1989) The Informational City: Information Technology, Economic Restructuring and the Urban-Regional Process, Oxford: Basil Blackwell.

— (1996) The Rise of the Network Society, Cambridge, Mass.: Basil Blackwell.

Chang, Ha-Joon (1998) 'Korea: the misunderstood crisis', World Development 26(8): 1555-61.

- (2000) 'The hazard of moral hazard: untangling the Asian crisis', World Development 28(4): 775-88.

Chen, Min (1995) Asian Management Systems: Chinese, Japanese and Korean Styles of Business, London: Routledge.

Chen, Tain-Jy (ed.) (1998) Taiwanese Firms in Southeast Asia: Networking Across Borders, Cheltenham: Edward Elgar.

Chiu, Catherine C. H. (1998) Small Family Business in Hong Kong: Accumulation and Accommodation, Hong Kong: Chinese University Press.

Chiu, Stephen W. K., Ho, Kong Chong and Lui, Tai-Lok (1997) City-States in the Global Economy: Industrial Restructuring in Hong Kong and Singapore, Boulder, Colo.: Westview.

Chu, Yen-Peng and Wu, Rong-I (eds) (1998) Business, Markets and Government in the Asia-Pacific, London: Routledge.

Collinge, Chris (1999) 'Self-organization of society by scale: a spatial reworking of regulation theory', Environment and Planning D: Society and Space 17(5): 557-74.

Contractor, Farok J. and Lorange, Peter (eds) (1988) Cooperative Strategies in International Business: Joint Ventures and Technology Partnerships between Firms, Lexington, Mass.: Lexington Books.

Cox, Kevin (ed.) (1997) Spaces of Globalization: Reasserting the Power of the Local, New York: Guildford. 
Crouch, Colin and Streeck, Wolfgang (eds) (1997) Political Economy of Modern Capitalism: Mapping Convergence and Divergence, London: Sage.

Deyo, Frederic C. (ed.) (1987) The Political Economy of the New Asian Industrialism, Ithaca, NY: Cornell University Press.

Dicken, Peter (1998) Global Shift: Transforming the World Economy, 3rd edn, London: Paul Chapman.

Dirlik, Arif (1997) 'Critical reflections on "Chinese capitalism" as paradigm', Identities 3(3): 303-30.

Doremus, Paul N., Keller, William W., Pauly, Louis W. and Reich, Simon (1998) The Myth of the Global Corporation, Princeton, NJ: Princeton University Press.

Douw, Leo M., Huang, Cen and Godley, Michael R. (eds) (1999) Qiaoxiang Ties: Interdisciplinary Approaches to 'Cultural Capitalism' in South China, London: Kegan Paul.

Doz, Yves L. and Hamel, Gary (1998) Alliance Advantage: the Art of Creating Value through Partnering, Boston, Mass.: Harvard Business School Press.

Dunning, John H. (1993) Multinational Enterprises and the Global Economy, Reading, Mass.: Addison Wesley.

— (1997) Alliance Capitalism and Global Business, London: Routledge.

East Asia Analytical Unit (1995) Overseas Chinese Business Networks in Asia, Parkes, Australia: Department of Foreign Affairs and Trade.

Eng, Irene (1997) 'Flexible production in late industrialization: the case of Hong Kong', Economic Geography 73(1): 26-43.

Enright, Michael J., Scott, Edith E. and Dodwell, David (1997) The Hong Kong Advantage, Hong Kong: Oxford University Press.

Fukuyama, Francis (1995) Trust: the Social Virtues and the Creation of Prosperity, London: Hamish Hamilton.

Fung, Victor (1997) 'Evolution in the management of family enterprises in Asia', in Gungwu Wang and Siu-lun Wong (eds) Dynamic Hong Kong: Business and Culture, Hong Kong: Hong Kong University Press, pp. 216-29.

Gereffi, Gary (1996) 'Global commodity chains: new forms of coordination and control among nations and firms in international industries', Competition and Change 1(4): 427-39.

Gerlach, Michael L. (1992) Alliance Capitalism: the Social Organization of Japanese Business, Berkeley: University of California Press.

Gertler, Meric S. (1995) "'Being there": proximity, organization, and culture in the development and adoption of advanced manufacturing technologies', Economic Geography 71(1): 1-26.

Goldman Sachs (1997) Chungkong Group: proposed restructuring, Goldman Sachs (Asia) LCC, Asian Pacific Finance Tower, 37th Floor, CitiBank Plaza, 3 Garden Road, Central Hong Kong, 10th January,

Gomez, Edmund Terence (1999) Chinese Business in Malaysia: Accumulation, Accommodation and Ascendance, Surrey: Curzon.

Grabher, Gernot and Stark, David (eds) (1997) Restructuring Networks in PostSocialist Societies: Legacies, Linkages and Localities, Oxford: Oxford University Press.

Guthrie, Douglas (1998) 'The declining significance of guanxi in China's economic transition', The China Quarterly 154: 254-82.

Hale, David D. (1998) 'The IMF, now more than ever: the case for financial peacekeeping', Foreign Affairs 77(6): 7-13.

Hamilton, Gary G. (ed.) (1991) Business Networks and Economic Development in East and South East Asia, Hong Kong: Centre of Asian Studies, University of Hong Kong. 
- (1997) 'Hong Kong and the rise of capitalism in Asia', in Gungwu Wang and Siu-lun Wong (eds) Dynamic Hong Kong: Business and Culture, Hong Kong: Hong Kong University Press, pp. 118-48.

Harmes, Adam (1998) 'Institutional investors and the reproduction of neoliberalism', Review of International Political Economy 5(1): 92-121.

Hassard, John, Law, John and Lee, N. (1999) 'Special themed section on Actornetwork theory and managerialism', Organization 6(3): 387-497.

Hefner, Robert W. (ed.) (1998) Market Cultures: Society and Values in the New Asian Capitalisms, Singapore: Institute of Southeast Asian Studies.

Held, David, McGrew, Anthony, Goldblatt, David and Perraton, Jonathan (1999) Global Transformations: Politics, Economics and Culture, Cambridge: Polity.

Henderson, Jeffrey (1999) 'Uneven crisis: institutional foundations of East Asian economic turmoil', Economy and Society 28(3): 327-68.

Higgott, Richard (1998) 'The Asian economic crisis: a study in the politics of resentment', New Political Economy 3(3): 333-55.

(1999) 'The political economy of globalisation in East Asia: the salience of "region building" ', in Kris Olds, Peter Dicken, Philip Kelly, Lily Kong and Henry Wai-chung Yeung (eds) Globalisation and the Asia Pacific: Contested Territories, London: Routledge, pp. 91-106.

Hirst, Paul and Thompson, Grahame (1996) Globalization in Question: the International Economy and the Possibilities of Governance, Cambridge: Polity.

Hodder, Rupert (1966) Merchant Princes of the East: Cultural Delusions, Economic Success and the Overseas Chinese in Southeast Asia, Chichester: John Wiley.

Hollingsworth, J. Rogers (1998) 'New perspectives on the spatial dimensions of economic coordination: tensions between globalization and social systems of production', Review of International Political Economy 5(3): 482-507.

Hollingsworth, J. Rogers and Boyer, Robert (eds) (1997) Contemporary Capitalism: the Embeddedness of Institutions, Cambridge: Cambridge University Press.

Horsman, Mathew and Marshall, Andrew (1994) After the Nation State: Citizens, Tribalism and the New World Disorder, London: HarperCollins.

Hsing, You-tien (1998) Making Capitalism in China: the Taiwan Connection, New York: Oxford University Press.

Jessop, Bob (1999) 'Some critical reflections on globalization and its illogic(s)', in Kris Olds, Peter Dicken, Philip Kelly, Lily Kong and Henry Wai-chung Yeung (eds) Globalisation and the Asia Pacific: Contested Territories, London: Routledge, pp. 19-38.

Johnson, Chalmers (1982) MITI and the Japanese Economic Miracle, Stanford, Calif.: Stanford University Press.

(1995) Japan: Who Governs? The Rise of the Developmental State, New York: W. W. Norton.

Kelly, Philip F. (1999) 'The geographies and politics of globalization', Progress in Human Geography 23(3): 379-400.

Kenny, Martin and Florida, Richard (1993) Beyond Mass Production: the Japanese System and Its Transfer to the U.S., New York: Oxford University Press.

Kim, Eun Mee (1997) Big Business, Strong State: Collusion and Conflict in Korean Development, Albany: SUNY Press.

Lane, Christel and Bachmann, Reinhard (1996) 'The social constitution of trust: supplier relations in Britain and Germany', Organization Studies 17(3): 365-95.

Issues and Empirical Applications, Oxford: Oxford University Press.

Lee, Yeon-ho (1997) The State, Society and Big Business in South Korea, London: Routledge. 
Lewis, Jordan D. (1995) The Connected Corporation: How Leading Companies Win Through Customer-Supplier Alliances, New York: The Free Press.

Low, Linda (1998) The Political Economy of a City-State: Government-Made Singapore, Singapore: Oxford University Press.

McNamara, Dennis L. (ed.) (1999) Corporatism and Korean Capitalism, London: Routledge.

McVey, Ruth (ed.) (1992) Southeast Asian Capitalists, Ithaca, NY: Cornell University Southeast Asia Program.

Magretta, Joan (1998) 'Fast, global, and entrepreneurial: supply chain management, Hong Kong style: an interview with Victor Fung', Harvard Business Review 76(5): 103-14.

Mair, Andrew (1994) Honda's Global Local Corporation, New York: St Martin's Press.

Mair, Andrew, Florida, Richard and Kenny, Martin (1988) 'The new geography of automobile production: Japanese transplants in North America', Economic Geography 64: 352-73.

Mathews, John A. (1997) 'A Silicon Valley of the east: creating Taiwan's semiconductor industry', California Management Review 39(4): 26-54.

- (1998) 'Fashioning a new Korean model out of the crisis: the rebuilding of institutional capabilities', Cambridge Journal of Economics 22(6): 747-59.

Mathews, John A. and Cho, D. S. (1998) Tiger Chips: the Creation of a Semiconductor Industry in East Asia, 1975-2000, Cambridge: Cambridge University Press.

Mathews, John A. and Snow, Charles C. (1998) 'A conversation with the Acer Groups' Stan Shih on global strategy and management', Organizational Dynamics 27(1): 65-74.

Mitchell, Katharyne (1995) 'Flexible circulation in the Pacific Rim: capitalism in cultural context', Economic Geography 71(4): 364-82.

Mittelman, James H. (ed.) (1996) Globalization: Critical Reflections, Boulder, Colo.: Lynne Rienner.

- (2000) The Globalization Syndrome: Transformation and Resistance, Princeton, NJ: Princeton University Press.

Murdoch, Jonathan (1997) 'Towards a geography of heterogeneous associations', Progress in Human Geography 21(3): 321-37.

- (1999) 'The spaces of actor-network theory', Geoforum 29(4): 357-74.

Nathan, Andrew (1993) 'Is Chinese culture distinctive?', Journal of Asian Studies 52(4): 923-36.

Nohria, Nitin and Ghoshal, Sumantra (1997) The Differentiated Network: Organizing Multinational Corporations for Value Creation, San Francisco, Calif.: Jossey-Bass.

O'Brien, Richard (1992) Global Financial Integration: the End of Geography, New York: Council on Foreign Relations Press.

Ohmae, Kenichi (1990) The Borderless World: Power and Strategy in the Interlinked Economy, London: Collins.

- (1995) The End of the Nation State: the Rise of Regional Economies, London: HarperCollins.

Olds, Kris (1998) 'Globalization and urban change: tales from Vancouver via Hong Kong', Urban Geography 19(4): 360-85.

Olds, Kris and Yeung, Henry Wai-chung (1999) '(Re)shaping "Chinese" business networks in a globalising era', Environment and Planning D: Society and Space 17(5): 535-55.

Olds, Kris, Dicken, Peter, Kelly, Philip, Kong, Lily and Yeung, Henry Wai-chung (eds) (1999) Globalisation and the Asia-Pacific: Contested Territories, London: Routledge.

Ong, Aihwa and Nonini, Donald (eds) (1997) Crossing the Edges of Empires: Culture, Capitalism, and Identity, London: Routledge. 
Orrù, Marco, Biggart, Nicole and Hamilton, Gary G. (1997) The Economic Organization of East Asian Capitalism, London: Sage.

Parry, B. (1998) 'Hunting the gene-hunters: the role of hybrid networks, status, and chance in conceptualising and accessing "corporate elites" ', Environment and Planning A 30(12): 2147-62.

Perry, Martin and Tan, Boon Hui (1998) 'Global manufacturing and local linkage in Singapore', Environment and Planning A 30(9): 1603-24.

Perry, Martin, Kong, Lily and Yeoh, Brenda (1997) Singapore: a Development City State, London: John Wiley.

Piven, Frances Fox (1995) 'Is it global economics or neo-laissez-faire?', New Left Review 213: 107-14.

Porter, Michael E. (1998) On Competition, Boston, Mass.: Harvard Business School Press.

Redding, S. Gordon (1990) The Spirit of Chinese Capitalism, Berlin: De Gruyter.

Reich, Robert B. (1991) The Work of Nations: Preparing Ourselves for 21st-Century Capitalism, London: Simon \& Schuster.

Richter, Frank-Jürgen (1999) Strategic Networks: the Art of Japanese Interfirm Cooperation, New York: International Business Press.

Rodan, Garry (1989) The Political Economy of Singapore's Industrialization: National State and International Capital, London: Macmillan.

Sassen, Saskia (1991) The Global City: New York, London, Tokyo, Princeton, NJ: Princeton University Press.

(1999) 'Servicing the global economy: reconfigured states and private agents', in Kris Olds, Peter Dicken, Philip Kelly, Lily Kong and Henry Waichung Yeung (eds) Globalisation and the Asia Pacific: Contested Territories, London: Routledge, pp. 149-62.

Sit, Victor F. S. and Wong, Siu Lun (1989) Small and Medium Industries in an Export-Oriented Economy: the Case of Hong Kong, Hong Kong: Centre of Asian Studies, University of Hong Kong.

Sorge, Arndt (1996) 'Societal effects in cross-national organization studies: conceptualizing diversity in actors and systems', in Richard Whitley and Peer Hull Kristensen (eds) The Changing European Firm: Limits to Convergence, London: Routledge, pp. 67-86.

Steers, Richard M. (1999) Made in Korea: Chung Ju Yung and the Rise of Hyundai, London: Routledge.

The Straits Times, Singapore, various issues.

Thornton, William H. (1998) 'Korean and East Asian exceptionalism', Theory, Culture and Society 15(2): 137-54.

Thrift, Nigel (1996) Spatial Formations, London: Sage.

- (1998) 'The rise of soft capitalism', in Andrew Herod, Gearóid Ó Tuathail and Susan M. Roberts, An Unruly World: Globalization, Governance and Geography, London: Routledge, pp. 25-71.

- (1999a) 'The place of complexity', Theory, Culture $\mathcal{E}$ Society 16(3): 31-69.

_ (1999b) 'The globalisation of business knowledge', in Kris Olds, Peter Dicken, Philip Kelly, Lily Kong and Henry Wai-chung Yeung (eds) Globalisation and the Asia Pacific: Contested Territories, London: Routledge, pp. 57-71.

Thrift, Nigel and Leyshon, Andrew (1994) 'A phantom state? The detraditionalisation of money, the international financial system and international financial centres', Political Geography 13: 299-327.

Tsang, Eric W. K. (1998) 'Can guanxi be a source of sustained competitive advantage for doing business in China?', Academy of Management Executive 12(2): 64-73. 
- (1999a) 'Internationalization as a learning process: Singapore MNCs in China', Academy of Management Executive 13(1): 91-101.

- (1999b) 'The knowledge transfer and learning aspects of international HRM: an empirical study of Singapore MNCs', International Business Review 8(5/6): 591-609.

Tsui-Auch, Lai Si (1999) 'Regional production relationship and developmental impacts: a comparative study of three regional networks', International Journal of Urban and Regional Research 23(2): 345-60.

UNCTAD (1998) World Investment Report 1998, New York: United Nations.

van Hoesel, Roger (1999) New Multinational Enterprises from Korea and Taiwan, London: Routledge.

Wade, Robert (1990) Governing the Market: Economic Theory and the Role of Government in East Asian Industrialization, Princeton, NJ: Princeton University Press.

Wade, Robert and Veneroso, Frank (1998) 'The Asian crisis: the high debt model versus the Wall Street-Treasury-IMF complex', New Left Review 228: 3-23.

Wang, Gungwu and Wong, Siu-lun (eds) (1997) Dynamic Hong Kong: Business and Culture, Hong Kong: Hong Kong University Press.

Weidenbaum, Murray and Hughes, Samuel (1996) The Bamboo Network: How Expatriate Chinese Entrepreneurs Are Creating a New Economic Superpower in Asia, New York: The Free Press.

Westney, D. Eleanor (1987) Imitation and Innovation: the Transfer of Western Organisational Patterns to Meiji Japan, Cambridge, Mass.: Harvard University Press.

Whatmore, Sarah (1997) 'Dissecting the autonomous self: hybrid cartographies for a relational ethics', Environment and Planning D: Society and Space 15: 37-53.

Whitley, Richard (1992) Business Systems in East Asia: Firms, Markets and Societies, London: Sage.

— (1994) 'The internationalization of firms and markets: its significance and institutional structuring', Organization 1(1): 101-24.

(1996) 'Business systems and global commodity chains: competing or complementary forms of economic organisation?', Competition and Change 1(4): 411-25.

(1998) 'Internationalization and varieties of capitalism: the limited effects of cross-national coordination of economic activities on the nature of business systems', Review of International Political Economy 5(3): 445-81.

- (1999) Divergent Capitalisms: the Social Structuring and Change of Business Systems, New York: Oxford University Press.

Whitley, Richard and Kristensen, Peer Hull (eds) (1996) The Changing European Firm: Limits to Convergence, London: Routledge.

- (eds) (1997) Governance of Work: the Social Regulation of Economic Relations, Oxford: Oxford University Press.

Windolf, Paul and Beyer, Jürgen (1996) 'Co-operative capitalism: corporate networks in Germany and Britain', British Journal of Sociology 47(2): 205-31.

Wong, Siu-lun (1988) Emigrant Entrepreneurs: Shanghai Industrialists in Hong Kong, Hong Kong: Oxford University Press.

Woods, M. (1998) 'Rethinking elites: networks, space, and local politics', Environment and Planning A 30(12): 2101-19.

Yao, Souchou (1997) 'The romance of Asian capitalism: geography, desire and Chinese business', in Mark T. Berger and Douglas A. Borer (eds) The Rise of Asia: Critical Visions of the Pacific Century, London: Routledge, pp. 211-40. 
Yeung, Henry Wai-chung (1994) 'Critical reviews of geographical perspectives on business organisations and the organisation of production: towards a network approach', Progress in Human Geography 18(4): 460-90.

(1997a) 'Business networks and transnational corporations: a study of Hong Kong firms in the ASEAN region', Economic Geography 73(1): 1-25.

(1997b) 'Cooperative strategies and Chinese business networks: a study of Hong Kong transnational corporations in the ASEAN region', in Paul W. Beamish and J. Peter Killing (eds) Cooperative Strategies: Asia-Pacific Perspectives, San Francisco, Calif.: The New Lexington Press, pp. 22-56.

- (1998a) 'The social-spatial constitution of business organisations: a geographical perspective', Organization 5(1): 101-28.

(1998b) 'Capital, state and space: contesting the borderless world', Transactions of the Institute of British Geographers 23(3): 291-309.

- (1998c) Transnational Corporations and Business Networks: Hong Kong Firms in the ASEAN Region, London: Routledge.

- (1998d) 'The political economy of transnational corporations: a study of the regionalisation of Singaporean firms', Political Geography 17(4): 389-416.

(1998e) 'Transnational economic synergy and business networks: the case of two-way investment between Malaysia and Singapore', Regional Studies 32(8): 687-706.

(1999a) 'Under siege? Economic globalisation and Chinese business in Southeast Asia', Economy and Society 28(1): 1-29.

(1999b) 'The internationalization of ethnic Chinese business firms from Southeast Asia: strategies, processes and competitive advantage' ${ }^{\prime}$ International Journal of Urban and Regional Research 23(1): 103-27.

(ed.) (1999c) The Globalisation of Business Firms from Emerging Economies, 2 vols, Cheltenham: Edward Elgar.

(1999d) 'Regulating investment abroad? The political economy of the regionalisation of Singaporean firms', Antipode 31(3): 245-73.

(2000a) 'Limits to the growth of family-owned business? The case of Chinese transnational corporations from Hong Kong', Family Business Review 12. (2000b) 'Economic globalisation, crisis, and the emergence of Chinese business communities in Southeast Asia', International Sociology 15(2): 269-90.

(2000c) 'A crisis of industrial and business networks in Asia? Asian networks in crisis?', Environment and Planning A 32(2): 191-200.

— (2000d) 'Neoliberalism, laissez-faire capitalism and economic crisis: the political economy of deindustrialisation in Hong Kong', Competition and Change 4: 121-69.

— (2000e) 'State intervention and neoliberalism in the globalising world economy: lessons from Singapore's regionalisation programme', The Pacific Review 13(1): 133-62.

Yeung, Henry Wai-chung and Olds, Kris (1998) 'Singapore's global reach: situating the city-state in the global economy', International Journal of Urban Sciences 2(1): 24-47.

- (eds) (2000) The Globalisation of Chinese Business Firms, London: Macmillan.

Yoshihara, Kunio (1988) The Rise of Ersatz Capitalism in South East Asia, Singapore: Oxford University Press. 